\title{
MENUMBUHKAN SIKAP SOSIAL MELALUI PEMBELAJARAN IPS SISWA SD HOME SCHOOLING PRIMAGAMA BANJARMASIN
}

\author{
Huriyah \\ Jurusan Pendidikan Guru Madrasah Ibtidaiyah \\ Universitas Islam Negeri Antasari Banjarmasin \\ J1. J. A. Yani KM. 4,5 Banjarmasin, Kalimantan Selatan, Indonesia \\ Email: huriyah.90.99@gmail.com \\ Website: https://jurnal.uin-antasari.ac.id/index.php/adzka \\ Received: 30 September 2019; Accepted: 13 Desember 2019; Published: 13 Desember 2019
}

\begin{abstract}
This study aims to foster social attitudes through social studies learning in students at Banjarmasin Primagama Home Schooling. Social attitudes of students can be known through social studies learning in elementary school students and how to foster social attitudes towards students who study at Primagama Banjarmasin Home Schooling through social studies learning. The researcher used qualitative research method. Data collection techniques were field observations, interviews, documentation, and triangulation. Data analysis in this study used an interactive model analysis, namely data reduction, data presentation, and conclusion. Based on the results of the study, it can be seen (1) that social studies learning at Banjarmasin Primagama Home Schooling can foster students' social attitudes by teaching instructors to provide social studies based on relevant, systematic, and infrastructure resources in accordance with the learning and community environment. (2) that instructors and psychologists evaluate the learning outcomes and the development of students' behavior so that they can foster social attitudes of students with a home schooling system.
\end{abstract}

Keywords : social attitude; IPS learning; home schooling.

\begin{abstract}
ABSTRAK
Penelitian ini bertujuan untuk menumbuhkan sikap sosial melalui pembelajaran IPS pada peserta didik di Home Schooling Primagama Banjarmasin. Melalui pembelajaran IPS yang diberikan oleh pengajar dapat mengetahui dan menumbuhkan sikap sosial siswa yang bersekolah di Home Schooling Primagama Banjarmasin. Peneliti menggunakan metode penelitian kualitatif, dengan teknik pengumpulan data berupa observasi lapangan, wawancara, dokumentasi, dan trianggulasi. Analisis data dalam penelitian ini menggunakan analisis model interaktif yaitu reduksi data, penyajian data, dan penarikan kesimpulan. Berdasarkan hasil penelitian dapat diketahui (1) bahwa pembelajaran IPS di Home Schooling Primagama Banjarmasin dapat menumbuhkan sikap sosial peserta didik dengan cara pengajar memberikan pembelajaran IPS berdasarkan sumber yang relevan, sistematis, dan sarana prasarana sesuai dengan lingkungan belajar dan lingkungan masyarakat. (2) pengajar, psikolog, melakukan evaluasi terhadap hasil belajar dan perkembangan tingkah laku peserta didik, sehingga dapat menumbuhkan sikap sosial peserta didik yang bersekolah dengan sistem home schooling.
\end{abstract}

Kata Kunci : sikap sosial; pembelajaran IPS; home schooling. 


\section{PENDAHULUAN}

Manusia merupakan kekuatan utama pada seluruh bidang pembangunan suatu bangsa. Secara nasional oleh sebab itu pembangunan pendidikan dilakukan secara terpadu dan berjalan secara bersamaan dengan pembangunan dengan bidang lain. Dalam peningkatan kualitas pembangunan nasional, pendidikan berfungsi sebagai katalisator di berbagai bidang, sebagai bagian integral dari sistem pembangunan nasional. Pendidikan dituntut menghasilkan seorang pendidik yang andal, professional, dan kreatif, serta efektif dan efisien (Rahmawati, 2019: 2).

Teknologi informasi semakin hari semakin berkembang dengan pesat dalam era globalisasi diberbagai bidang kehidupan. Termasuk bidang pendidikan yang juga mengikuti perkembangan pengetahuan dan teknologi. Manusia memerlukan pendidikan. Sebagai generasi penerus, generasi muda dituntut ikut berperan aktif dalam memajukan pendidikan agar menciptakan sumber daya manusia yang berkualitas dan cerdas. Mewujudnya sumber daya manusia yang berkualitas perlu niat dan tekat yang kuat pada diri manusia itu sendiri. Pergerakan globalisasi dan modernisasi memunculkan masalah sosial diantaranya individualisme. Sikap individualisme terlihat pada ketidakpedulian terhadap sesama dan menyebabkan menipisnya perilaku prososial pada remaja atau memunculkan perilaku antisosial (Aziz, 2003).

Pendidikan dasar merupakan tahapan penting bagi generasi muda untuk menanamkan nilai-nilai kehidupan. Pendidikan dasar menjadi dasar utama tentang membentuk cara berpikir, berperilaku dan bersikap dalam menjalani kehidupan. Pendidikan merupakan usaha untuk meningkatkan taraf kesejahteraan pada kehidupan manusia, karena pendidikan merupakan bagian dari pembangunan nasional dalam menghadapi perubahan era reformasi dan globalisasi. Pendidikan dasar bertujuan untuk membentuk karakter, kecakapan dasar dan kemampuan yang berguna bagi kehidupan semua warga negara (Rahmawati, 2019: 2).

Pendidikan bagian utama dari pembentukan sikap sosial. Ada berbagai jalur pendidikan yaitu jalur formal, non-formal, dan informal. Salah satu penilaian dalam pendidikan yaitu penilaian sikap. Berdasarkan Peraturan Menteri Pendidikan dan Kebudayaan Republik Indonesia Nomor 23 Tahun 2016 tentang Standar Penilaian Pendidikan menyatakan penilaian sikap tentang perilaku peserta didik. Sikap sosial salah satu dikembangkan di sekolah, berdasarkan Kurikulum 2013 dilakukan pada Kompetensi Inti 2 (KI-2). Usia anak sekolah dasar 6-13 penting dikembangkan sikap sosial, terlebih pada peserta didik yang bersekolah informal seperti Home Schooling yang kurang interaksi dengan banyak orang dan lingkungan (Depdikbud, 2013).

Sekolah merupakan sebuah sarana bagi peserta didik untuk belajar, berinteraksi, berkumpul dan bermain dengan pengajar dan peserta didik yang lain. Jika peserta didik tidak memiliki sikap sosial yang baik, maka peserta didik akan sulit berinteraksi dan beradaptasi dengan orang lain dalam kehidupan. Peserta didik yang bersekolah di Home Schooling cenderung memiliki kepribadian individual, tidak peduli terhadap orang lain, kurang bekerja sama dan kurang menghargai orang lain.

Pembelajaran IPS merupakan salah satu pelajaran yang dapat menumbuhkan sikap dan nilai sosial dalam diri peserta didik. Dalam pembelajaran IPS dikembangkan nilai dan sikap sosial di dalam tujuan pembelajaran pada ranah kognitif, psikomotor, afektif. Pembelajaran IPS berawal dari cabang pengetahuan kehidupan manusia sehari-hari. Diharapkan dalam pembelajaran IPS dapat membentuk peserta didik yang bersekolah Home Schooling menjadi peserta didik yang aktif dan saling menghargai dalam kehidupan sosial di masyarakat. Sehingga peserta didik bisa memahami peristiwa dan perubahan yang terjadi, memiliki rasa tanggung jawab dan saling menghormati dengan sesama. Selain itu peserta didik mudah berinteraksi dengan lingkungan, diterima di masyarakat dan dapat menghadapi masalah dalam kehidupan (Sapriya, 2009). 


\section{A. Sikap Sosial}

Menurut Abu Ahmadi sikap sosial adalah individu sadar dalam menentukan kegiatan nyata dan terus-menerus terhadap objek sosial. Sekelompok orang menyatakan sikap sosial secara berulang-ulang disebut objek sosial. Menurut Chaplin mendefinisikan sikap sosial (sosial attitudes) yaitu (1) kecenderungan bersikap dengan cara tertentu kepada orang lain; (2) sebuah pendapat umum; dan (3) sikap yang terarah pada tujuan sosial yang berbanding terbalik pada tujuan pribadi. Pendapat Sudarsono sikap sosial yaitu suatu perbuatan sikap yang tegas dari individu atau kelompok dalam keluarga atau masyarakat. (Kartini Kartono, 2006: 469). Berdasarkan definisi yang disebutkan para ahli dapat disimpulkan sikap sosial adalah kesadaran individu dalam mementukan suatu perbuatan nyata untuk bersikap atau bertingkah laku dengan cara tertentu kepada orang lain dengan mementingkan tujuan sosial dibanding tujuan pribadi dalam kehidupan bermasyarakat (Ahmadi, 2007).

Menurut Baron dan Byrne sumber yang membentuk sikap dengan cara meniru sikap orang lain melalui pembelajaran sosial. Cara pandang saat berinteraksi dengan orang lain atau dengan mencari tahu tingkah laku orang lain. Pembelajaran sosial bisa terjadi dengan melalui beberapa proses sosial yaitu:

a. Classical conditioning adalah pembelajaran yang berbasis asosiasi, ketika pemberian stimulus secara berulang-ulang dan stimulus yang pertama menandai munculnya stimulus yang mengikutinya.

b. Instrumental conditioning yaitu pembelajaran mempertahankan pandangan yang benar.

c. Observational learning yaitu pembelajaran dari contoh dengan observasi, ketika seseorang mempelajari pemikiran atau tingkah laku yang baru dari orang lain.

d. Perbandingan sosial yakni perbandingan diri sendiri dengan orang lain dalam menentukan pandangan hidup antara benar atau salah.

Indikator dalam penelitian ini adalah menunjukkan sikap terbuka dan peduli kepada orang lain, menunjukkan pendapat, bisa bekerjasama, membuat suasana yang komunikatif, membentuk sikap tanggung jawab dan menghargai orang lain, serta membentuk sikap suka menolong orang lain.

Penilaian hasil belajar siswa di sekolah salah satunya yaitu penilaian sikap. Sesuai dengan peraturan Menteri Pendidikan dan Kebudayaan Republik Indonesia Nomor 23 Tahun 2016 yaitu tentang Standar Penilaian Pendidikan di dalamnya menyebutkan penilaian sikap adalah kegiatan yang harus dilakukan oleh pendidik untuk mendapatkan informasi secara deskripsi dari penilaian sikap siswa. Pada kurikulum 2013 penilaian sikap sosialdapat dilakukan berdasarkan Kompetensi Inti 2 (KI-2). Sikap sosial perlu dikembangkan pada usia anak sekolah dasar yaitu pada umur 6 sampai 12 tahun, sebab pada usia tersebut tahap yang penting dalam membentuk karakter anak yang sedang mengalami pertumbuhan fisik dan perkembangan motorik, kognitif, emosional, moral, bahasa, dan sosial.

\section{B. Pembelajaran IPS}

Istilah IPS atau Ilmu Pengetahuan Sosial adalah mata pelajaran pada tingkat sekolah dasar (SD) dan tingkat menengah pertama. Istilah IPS juga terdapat di perguruan tinggi identic dengan nama social studies. Pembelajaran IPS di sekolah dasar adalah mata pelajaran yang berdiri sendiri dan merupakan integrasi dari sejumlah konsep disiplin ilmu sosial, sains, humaniora, serta isu dan masalah social dalam kehidupan. Materi pembelajaran IPS pada jenjang sekolah dasar tidak terlihat adanya aspek disiplin ilmu, sebab lebih mementingkan pada dimensi pedagogik dan psikologis yang bersifat holistik pada karakteristik kemampuan berpikir siswa. (Sapriya, 2009: 20-21)

Ilmu Pengetahuan Sosial (IPS) merupakan pelajaran yang menggabungkan konsep dasar dari ilmu sosial, disusun menggunakan pendekatan pendidikan dan psikologis sehingga bermakna bagi peserta didik di kehidupannya. Menurut Trianto (2010: 171) mengatakan Ilmu Pengetahuan Sosial berdasarkan realitas dan fenomena sosial dengan pendekatan interdisipliner dari aspek dan cabang ilmu sosial. Menurut Djodjo Suradisastra dkk (1991: 4), IPS merupakan pokok kajian tentang manusia dan lingkungannya. Manusia tidak bisa hidup sendiri atau saling ketergantungan, harus tolong-menolong dengan orang lain dengan lingkungannya sehingga 
muncul hubungan antar sesama. Pendapat Ichas H. A dan Tuti Istianti I (2006: 9-10) menyatakan dalam materi pembelajaran IPS sebuah wadah pembelajaran dan memperoleh pengetahuan seiring perkembangan diri dan lingkungan peserta didik (Suwarma, 2014).

Berdasarkan pendapat beberapa ahli mengenai pembelajaran IPS dapat disimpulkan bahwa IPS merupakan pembelajaran tentang gejala dan masalah sosial dalam aspek kehidupan lingkungan masyarakat. Pembelajaran IPS bertujuan agar peserta didik dapat menghadapi masalah sosial pada masa sekarang maupun masa mendatang dalam kehidupan peserta didik maupun lingkungan masyarakat (Hidayati, 2002).

Buchari Alma (2010: 6), mengemukakan tujuan utama pembelajaran IPS di SD adalah mengembangkan potensi peserta didik agar peka kepada masalah sosial yang terjadi dimasyarakat, dapat mengatasi masalah yang terjadi di masyarakat, bersikap positif terhadap ketimpangan yang terjadi pada diri sendiri dan di masyarakat. Mata pelajaran IPS di Sekolah Dasar bertujuan agar peserta didik dapat memahami dan mengembangkan ilmu pengetahuan dan keterampilan sosial dasar agar berguna bagi peserta didik dalam lingkungan dan kehidupan peserta didik sehari-hari. Selain itu tujuan dari pembelajaran IPS agar peserta didik dapat mengembangkan pemahaman dalam masyarakat dari masa lalu hingga masa sekarang, sehingga memiliki rasa kebanggaan dalam diri peserta didik sebagai bangsa Indonesia (Kurikulum Pendidikan Dasar, 1993: 120). Djodjo Suradisastra dkk (1991: 9-11), menyebutkan ruang lingkup pembelajaran IPS di Sekolah Dasar (SD) adalah sebagai berikut:

1. Kelas I SD mengenalkan tentang keluarga dan lingkungan.

2. Kelas II SD mempelajari lingkungan dan komunitas peserta didik pada wilayah yang berbeda, dalam satu negara atau berbeda negara.

3. Kelas III mempelajari tentang komunitas sendiri dan luar negeri membahas tentang kebutuhan pangan, sandang, dan papan, serta komunikasi dan trasportasi pada masyarakat kota.

4. Kelas IV mempelajari tentang wilayah lingkungan dan kebudayaan di dunia.

5. Kelas V mempelajari tentang sejarah, geografi dan sosiologi serta antropologi dari Negara Indonesia dan Negara tetangga

6. Kelas VI mempelajari tentang sejarah, geografi dan sosiologi serta antropologi dari Negara yang ada di dunia terutama sebelah timur.

Berdasarkan pendapat diatas tujuan pembelajaran IPS yaitu mendidik dan membekali kemampuan dasar pada peserta didik agar dapat mengembangkan diri sesuai dengan kemampuan, bakat dan minat peserta didik di dalam lingkungannya. Tujuan pembelajaran IPS pada penelitian ini adalah agar peserta didik dapat mengembangkan sikap sosial, peka terhadap lingkungan, dan dapat mengatasi masalah yang dihadapi di lingkungan dan masyarakat (Suradisastra, 2011).

\section{Home Schooling}

Menurut Abdurrahman (2007), secara harfiah Home Schooling artinya sekolah di rumah. Ketika orang tua keberatan atau merasa kesulitan menyekolahkan anaknya karena alasan-alasan tertentu, Home Schooling menjadi alternatif pilihan orang tua untuk mendapatkan pendidikan. Menurut Ella Yulaelawati, Home Schooling merupakan suatu layanan pendidikan yang dilakukan oleh orang tua dan masyarakat secara sadar, teratur, dan terarah dimana kondisi belajar dibuat kondusif. Proses belajar berlangsung secara kondusif dengan tujuan setiap anak mempunyai potensi yang unik dan berbeda-beda, sehingga perkembangan anak berjalan secara maksimal. Lembaga-lembaga pendidikan menggunakan rumusan yang sama sebagai sarana penyedia program Home Schooling (Ma'mur, 2009).

Undang-undang No. 20 tahun 2003 ayat 10 yang berbunyi "Kegiatan pendidikan informal yang dilakukan oleh keluarga dan lingkungan berbentuk kegiatan belajar secara mandiri". Maksud dari ayat tersebut yaitu sistem Pendidikan Nasional mengakomodasi sebagai salah satu alternatif pembelajaran yang dapat dilakukan oleh masyarakat. Dalam pelaksanaannya home 
schooling dinaungi oleh Direktorat Pendidikan Kesetaraan dan Kementerian Pendidikan Nasional.

Ada beberapa kelebihan siswa yang bersekolah dengan sstem home schooling yaitu sebagai berikut:

1. Bisa memaksimalkan bakat dan potensi peserta didik semenjak usia dini.

2. Dapat memberikan peluang yang besar kepada peserta didik agar bisa mandiri dan kreatif secara individual.

3. Kemampuan bergaul yang lebih luas kepada orang yang berbeda usia.

4. Membentuk peserta didik untuk lebih siap terjun ke lingkungan sosial yang lebih luas, karena materi pembelajaran berdasarkan kegiatan sehari-hari.

5. Dapat menumbuhkan nilai dan sikap sosial peserta didik

Beberapa kekurangan dari home schooling yaitu sebagai berikut :

1. Diperlukan keterlibatan dan komitmen orang tua yang tinggi

2. Sosialisasi kepada teman sebaya lebih rendah

3. Ada resiko kemampuan yang kurang untuk bisa bekerja dalam sebuah tim.

\section{METODE PENELITIAN}

Metode penelitian yang digunakan pada penelitian ini yaitu metode penelitian kualitatif. Menurut Bogdan dan Taylor (2005: 4) penelitian kualitatif merupakan prosedur penelitian yang memberikan data deskriptif yaitu data tertulis dan data lisan dari subjek penelitian yang bisa diamati. Pemilihan metode kualitatif dalam penelitian ini karena lebih mudah berhadapan langsung dengan kenyataan yang dihadapi oleh peneliti di lapangan. Selain itu metode kualitatif berhubungan langsung antara peneliti dengan informan serta lebih bisa menyesuaikan pada penajaman pengaruh dan pola-pola nilai yang ada (Moloeong, 2005: 7).

Sumber data dalam penelitian ini sebagian besar menggunakan data kualitatif yaitu diperoleh dari narasumber, tempat, kegiatan atau aktivitas, dan dokumentasi. Dokumen yang diteliti pada penelitian ini data jumlah peserta didik di Home Schooling Primagama Banjarmasin, data dan analisis perkembangan anak. Sumber data diatas diharapkan dapat memberikan informasi tentang sikap sosial peserta didik melalui pembelajaran IPS pada peserta didik Sekolah Dasar (SD) dan cara menumbuhkan sikap sosial terhadap peserta didik yang bersekolah di Home Schooling Primagama Banjarmasin melalui pembelajaran IPS. Tempat penelitian dilakukan di Home Schooling Primagama Banjarmasin pada peserta didik SD dari kelas I sampai dengan kelas VI. Penelitian ini berlangsung selama satu bulan yaitu peneliti mengumpulkan informasi berupa data sekolah dan mengikuti aktifitas belajar IPS sebanyak dua pertemuan. Narasumber dalam penelitian ini yaitu kepala sekolah, pengajar IPS yang mengajar pada jenjang SD, psikolog Home Schooling Primagama Banjarmasin, serta orang tua dari peserta didik jenjang SD.

Berdasarkan metode penelitian kualitatif teknik pengumpulan data dalam penelitian ini yaitu 1) wawancara yang bersifat terbuka dan dilakukan secara berulang-ulang kepada informan yang sama. 2) observasi berguna dalam menggali data dari berbagai sumber data antara lain tempat penelitian, peristiwa yang terjadi, dan rekaman gambar. 3) pencatatan dokumen berguna untuk melengkapi data saat melaksanakan wawancara dan observasi. 4) analisis dokumen berguna untuk mengumpulkan data dokumen sebagai sumber data untuk menafsirkan, menguji (Moleong, 2005: 161).

Analisis data dalam penelitian kualitatif bersifat induktif yaitu penarikan simpulan bersifat umum dari data-data dilapangan. Penelitian ini menggunakan analisis model interaktif (Sugiyono, 2007). Model analisis interaktif yaitu sebagai berikut :

1. Reduksi data dengan cara seleksi, klasifikasi, dan memfokuskan data lapangan.

2. Penyajian data dengan deskripsi data-data sesuai dengan pokok masalah 
3. Penarikan simpulan dengan mengambil kesimpulan berdasarkan reduksi dan penyajian data.

\section{HASIL PENELITIAN DAN PEMBAHASAN}

Jumlah pengajar yang mengajar di Home Schooling Primagama Banjarmasin pada jenjang SD sebanyak 9 orang, sedangkan jumlah peserta didik SD di Home Schooling Primagama Banjarmasin berjumlah 16 orang. Pendidikan pengajar rata-rata berjenjang S1, psikolog 1 orang berjenjang S2 dan staf administrasi sebanyak 2 orang dengan jenjang pendidikan S1. Pengajar yang mengajarkan pembelajaran IPS di Home Schooling Primagama Banjarmasin jenjang SD berlatar belakang pendidikan Geografi. Berdasarkan hasil pengamatan saat pelaksanaan pembelajaran IPS di Home Schooling Primagama Banjarmasin pada jenjang Sekolah Dasar (SD) diketahui peran pengajar dalam proses pembelajaran dimulai dari mempersiapkan peserta didik dalam memulai pelajaran atau pengajar melakukan apersepsi pembelajaran. Dalam proses pembelajaran pengajar mengkaitkan materi pembelajaran dengan kejadian fenomena yang terjadi di lingkungan masyarakat dan relevan. Pengajar memberikan penjelasan materi secara jelas dan terstruktur. Selain itu pengajar juga memberikan contoh yang sering di temui peserta didik pada realitas kehidupan.

Psikolog yang ada di Home Schooling Primagama Banjarmasin berperan dalam menyelidiki proses belajar dan mengajar pengajar, serta mengembangkan prinsip psikologis dan teknik yang berlaku dalam pendidikan. Psikolog berfungsi membantu peserta didik untuk bisa belajar secara maksimal dan membantu pengajar untuk bisa mengajarkan pelajaran dengan baik. Psikolog di Home Schooling Primagama Banjarmasin bekerja bersama-sama dengan orang tua, pengajar, dan pihak sekolah agar menciptakan lingkungan belajar yang nyaman, aman, sehat, dan dekat dengan keluarga serta lingkungan. Adapun tugas psikolog yaitu mengoptimalkan dan menyampaikan hasil tes dan perkembangan peserta didik bersamaan dengan informasi dari dan orang tua untuk menganalisis kondisi peserta didik. Kemudian memberikan nasihat kepada peserta didik dan orang tua agar membantu menyelesaikan permasalahan dan tingkah laku peserta didik. Serta memberikan konsultasi kepada peserta didik, orang tua, pengajar, administrator, dan pihak-pihak lain yang terkait mengenai topic seputar sekolah dan pendidikan belajar, seperti gaya belajar, teknik dalam memodifikasi perilaku dan lain sebagainya.

Pengajar melaksanakan proses pembelajaran berdasarkan kompetensi yang akan dicapai sesuai dengan kurikulum 2013. Pengajar melaksanakan pembelajaran yang bersifat kontekstual dan melaksanakan pembelajaran yang dapat memungkinkan tumbuhnya sikap sosial. Pengajar menggunakan media pembelajaran dalam kegiatan pembelajaran yaitu berupa gambar kelompok manusia dalam kegiatan sehari-hari. Pengajar menjelaskan materi sosial dan memberikan contoh-contoh dalam berinteraksi sosial dan materi disampaikan dengan gaya bahasa yang sesuai, sehingga peserta didik dapat memahami penjelasan dari pengajar dan dapat mempraktikkanya dalam kehidupan masyarakat. Pengajar berusaha menciptakan suasana belajar yang kondusif agar bisa memicu keterlibatan peserta didik, membuat peserta didik aktif dalam pembelajaran, serta menumbuhkan keceriaan dan antusias peserta didik dalam belajar Ilmu Pengetahuan Sosial (IPS).

Selama proses pembelajaran dan setalah pembelajaran selesai pengajar melakukan pemantauan kemajuan belajar peserta didik dan sikap peserta didik, serta pengajar melakukan penilaian sesuai dengan kompetensi. Selain itu pengajar melakukan refleksi dan membuat rangkungan bersama peserta didik. Pengajar juga melaksanakan evaluasi pembelajaran IPS pada akhir pelajaran. Kemudian pengajar menutup pelajaran dengan berdoa bersama.

Berdasarkan hasil pengamatan dan wawancara dengan Kepala Sekolah, pengajar mata pelajaran IPS, dan psikolog Home Schooling Primagama Banjarmasin. Memperoleh data lapangan yaitu sekolah menyediakan buku teks pelajaran IPS, buku referensi yang relevan 
dengan pembelajaran IPS walaupun masih terbatas jumlahnya. Evaluasi perlu dilakukan karena bagian yang penting pada akhir kegiatan pembelajaran. Evaluasi pembelajaran dilakukan agar mengetahui tingkat keberhasilan dan capaian tujuan pembelajaran selama proses pembelajaran. Hasil dari evaluasi yang dilakukan pengajar mata pelajaran IPS dirangkum dalam sebuah jurnal harian pengajar dan peserta didik. Psikolog juga memberikan pelajaran berupa penyuluhan konseling kepada peserta didik dan orang tua peserta didik. Kemudian hasil belajar dan perkembangan peserta didik bersama psikolog dirangkum dan ditarik kesimpulan terhadap perkembangan peserta didik, termasuk sikap sosial peserta didik. Berikut hasil yang didapatkan berdasarkan hasil observasi dan wawancara dapat dilihat dari tabel berikut.

Tabel 1. Sikap Sosial yang Ditumbuhkan Melalui Pembelajaran IPS di Homeschooling Primagama Banjarmasin

\begin{tabular}{|c|c|c|c|c|}
\hline No & Variabel & Aspek pengamatan & Sub Aspek & Deskripsi \\
\hline \multirow[t]{2}{*}{1.} & \multirow[t]{2}{*}{$\begin{array}{l}\text { Pembelajaran } \\
\text { IPS }\end{array}$} & \multirow[t]{2}{*}{ Nilai-nilai sosial } & $\begin{array}{l}\text { Interaksi } \\
\text { sosial }\end{array}$ & $\begin{array}{l}\text { Siswa dapat berinteraksi dengan } \\
\text { siswa lain dan guru di dalam } \\
\text { sekolah. Di luar sekolah siswa } \\
\text { menjadi lebih peka terhadap orang } \\
\text { disekitarnya }\end{array}$ \\
\hline & & & $\begin{array}{l}\text { Perduli } \\
\text { terhadap } \\
\text { orang lain }\end{array}$ & $\begin{array}{l}\text { Terbentuk jiwa sosial terlihat dari } \\
\text { keperdulian dan perhatian siswa } \\
\text { kepada orang lain yang ada } \\
\text { disekitarnya. }\end{array}$ \\
\hline \multirow[t]{3}{*}{2.} & \multirow[t]{3}{*}{$\begin{array}{l}\text { Sikap sosial } \\
\text { siswa }\end{array}$} & \multirow[t]{3}{*}{$\begin{array}{l}\text { Aktivitas siswa dalam } \\
\text { proses pembelajaran } \\
\text { IPS }\end{array}$} & $\begin{array}{l}\text { Sikap dalam } \\
\text { diri siswa }\end{array}$ & $\begin{array}{l}\text { Siswa dapat menunjukkan sikap } \\
\text { mandiri, disiplin, dan mempunyai } \\
\text { sikap tanggung jawab terhadap } \\
\text { dirinya sendiri. Siswa mengetahui } \\
\text { perannya di lingkungan sekitar }\end{array}$ \\
\hline & & & $\begin{array}{l}\text { Bersikap } \\
\text { dengan orang } \\
\text { lain }\end{array}$ & $\begin{array}{l}\text { Siswa menunjukkan sikap ramah } \\
\text { kepada teman dan guru di sekolah, } \\
\text { saling berbagi dan menolong kepada } \\
\text { sesama. Siswa bisa bekerja sama } \\
\text { dalam tugas kelompok, serta } \\
\text { membantu teman } \\
\text { pembelajaran. }\end{array}$ \\
\hline & & & $\begin{array}{l}\text { Menunjukka } \\
\text { n tujuan } \\
\text { sosial }\end{array}$ & $\begin{array}{l}\text { Siswa dapat menentukan bahwa } \\
\text { kepentingan sosial lebih diutamakan } \\
\text { dari pada kepentingan pribadi. }\end{array}$ \\
\hline
\end{tabular}

Kompetensi atau kemampuan pengajar mata pelajaran IPS jenjang SD di Home Schooling Primagama Banjarmasin dari kualifikasi pendidikan akademik memenuhi syarat, karena lulusan S1 pendidikan geografi sesuai dengan rumpun pendidikan bidang IPS. Berdasarkan hasil observasi selama proses pembelajaran berlangsung, pengajar mata pelajaran IPS sudah mempersiapkan perangkat administrasi pembelajaran IPS sebagai persiapan awal dalam proses pembelajaran. Pengajar mata pelajaran IPS melakukan ulangan harian dan ulangan tengah semester, serta ulangan akhir semester, dan melakukan analisis hasil belajar peserta didik. Pengajar juga melakukan evaluasi terhadap tingkah laku dan perkembangan peserta didik secara berkala.

Pembelajaran IPS berjalan sesuai dengan yang diharapkan sehingga pengajar perlu melakukan berbagai persiapan. Dari hasil wawancara kepada pengajar mata pelajaran IPS di Home Schooling Primagama Banjarmasin diketahui bahwa persiapan yang dilakukan yaitu membuat perangkat pembelajaran selama satu semester, pengisian jurnal harian perkembangan peserta didik secara teratur setiap kali memberikan pelajaran, membuat dan menerapkan metode pembelajaran IPS yang sesuai untuk membentuk karakter dan menunbuhkan sikap sosial 
peserta didik, membuat media pembelajaran yang dapat menarik perhatian peserta didik, serta penyediaan sarana dan prasarana sekolah yang mendukung pembelajaran.

Hasil pengamatan dan wawancara sumber belajar yang digunakan oleh pengajar dalam pembelajaran IPS dengan memanfaatkan buku teks pelajaran IPS pada jenjang SD, media cetak berupa gambar, dan menggunakan lingkungan yang ada disekitar sebagai sumber belajar. Dalam pengamatan saat penelitian di Home Schooling Primagama Banjarmasin sebelum pembelajaran pengajar melakukan evaluasi pembelajaran IPS dengan memberikan pertanyaan tentang permasalah sosial yang sedang marak terjadi, sehingga dapat menumbuhkan motivasi dan kepekaan peserta didik terhadap keadaan sosial di sekitarnya. Setelah memberikan motivasi berupa pertanyaan pengajar memberikan materi pelajaran IPS kepada peserta didik berupa penjelasan materi dan mengkaitkan dengan keadaan sosial lingkungan masyarakat, sehingga dapat menumbuhkan nilai dan sikap sosial yang tinggi kepada peserta didik Home Schooling Primagama Banjarmasin. Pembelajaran berfokus pada pengajar atau teacher certered yang mana pengajar mata pelajaran IPS berperan penting dalam membentuk sikap sosial peserta didik agar peserta didik bisa berinteraksi dan beradaptasi terhadap lingkungan dan masyarakat. Pengajar melakukan evaluasi di akhir pembelajaran dengan memberikan tugas kepada peserta didik mengenai hal-hal yang dilakukan sehari-hari dalam berinteraksi dengan teman sebaya dan dengan orang di sekitar lingkungan tempat tinggal peserta didik.

Pembelajaran IPS dapat membentuk kepekaan sosial pada peserta didik dengan memberikan pemahaman bahwa peserta didik bisa menyadari reaksi dari orang lain dan memahami tindakan yang dilakukan. Peserta didik bisa berbicara kepada orang lain dan menyampaikan informasi secara efektif, serta dapat mengkomunikasikan melalui tulisan sesuai dengan kebutuhan masyarakat.

\section{PENUTUP}

Berdasarkan hasil penelitian yang dilakukan di Homeschooling Primagama Banjarmasin pada jenjang sekolah dasar (SD) kesimpulan yang dapat diambil dari hasil wawancara dengan pihak sekolah dan siswa diketahui bahwa lingkungan sekolah bisa menumbuhkan sikap social, salah satunya dari pembelajaran IPS. Penumbuhan sikap sosial pada siswa dari nilai-nilai sosial yang ada dalam pembelajaran IPS yaitu interaksi sosial dan adanya sikap perduli kepada orang lain, terlihat dari aktivitas siswa dalam pembelajaran IPS. Siswa memperlihatkan sikap mandiri, disiplin, dan tanggung jawab terhadap dirinya sendiri, serta siswa mengetahui perannya dalam lingkungan sekitar. Dalam bersikap dengan orang lain siswa menunjukkan sikap ramah kepada orang lain di sekitarnya, saling berbagi dan menolong antar sesama. Dengan pembelajaran IPS siswa dapat menunjukkan tujuan dari nilai sosial yang mana lebih mengutamakan kepentingan sosial dari pada kepentingan pribadi.

Pengajar dan psikolog melakukan evaluasi hasil belajar dan perkembangan tingkah laku peserta didik dalam menumbuhkan sikap sosial peserta didik sebelum, saat proses, dan setelah proses pembelajaran IPS berlangsung, dengan pengajar mengisi jurnal perkembangan peserta didik dan psikolog membantu peserta didik untuk bisa belajar secara maksimal dan membantu pengajar untuk bisa mengajarkan pelajaran dengan baik. Kedepannya pengajar mata pelajaran IPS dapat terus meningkatkan kompetensi yang lebih untuk menumbuhkan sikap-sikap yang baik untuk peserta didik. Pengajar diharapkan dapat terus mengembangkan pembelajaran IPS secara kreatif dan inovatif dengan menggunakan metode pembelajaran dan media pembelajaran yang lebih variatif, sehingga tujuan-tujuan pembelajaran dapat tercapai.

\section{DAFTAR PUSTAKA}

Abu, A. (2007). Psikologi Sosial. Jakarta: Rineka Cipta.

Al Muchtar, S. (2014). Inovasi dan Transformasi Pembelajaran Pendidikan IPS. Bandung: Gelar Putaka Mandiri. 
Arikunto, S. (2010). Manajemen Penelitian. Jakarta: Rineka Cipta.

Azis, A. 2003. Memahami Fenomena Sosial Melalui Studi Kasus. Jakarta: PT. Rajagrafindo Persada.

David, O. S. dkk. (2009). Social Psichology. Jakarta: Erlangga.

Departemen Pendidikan dan Kebudayaan. (2013). Kurikulum Pendidikan Dasar. Jakarta: Depdikbud.

Djodjo, S. dkk. (2011). Pendidikan IPS 3. Jakarta: Depdikbud.

Elizabeth, B. H. (2009). Developmental Psycology. Jakarta: Erlangga.

Hidayati. (2002). Pendidikan IPS di Sekolah Dasar. Yogyakarta: FIP UNY.

Chaplin, J. P. (2006). Dictionary of Psychology. Jakarta: Grafindo.

Kartono, K. (2002). Patologi Sosial 2. Jakarta: Rajawali Press.

Ma'mur, J. A. (2009). Buku Pintar Home Schooling. Ciputat: Flash Books.

Peraturan Menteri Pendidikan Dan Kebudayaan Republik Indonesia Nomor 23 Tahun 2016 Tentang Standar Penilaian Pendidikan

Rahmawati, Vol. 9 Nomor 1 Juni 2019, "Problem Kepemimpinan Pendidikan Madrasah Ibtidaiyah dalam Pembangunan Mutu Sumber Daya Manusia" Al-Adzka: Jurnal Ilmiah Pendidikan Guru Madrasah Ibtidaiyah, hal. 2

Rizemi, S. P. (2009). Panduan Pendidikan Berbasis Bakat Siswa. Yogyakarta: Diva Press

Robert, A. B. \& Donn, B. (2009). Social Psychology. Jakarta: Erlangga.

Sapriya. (2009). Pendidikan IPS Konsep dan Pembelajaran. Bandung: PT. Rosdakarya.

Sudarsono. (2007). Kamus Konseling. Jakarta: Rineka Cipta

Sugiyono. (2007). Metode Penelitian Pendidikan (Pendekatan Kuantitatif, Kualitatif dan R\&D). Bandung: Alfabeta. 
Huriyah 